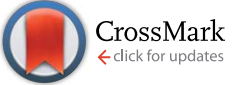

Cite this: RSC Adv., 2015, 5, 90235

Received 28th June 2015 Accepted 9th October 2015

DOI: $10.1039 / c 5 r a 12505 g$

www.rsc.org/advances

\section{The promotional role of $\mathrm{Ce}$ in $\mathrm{Cu} / \mathrm{ZSM}-5$ and in situ surface reaction for selective catalytic reduction of $\mathrm{NO}_{x}$ with $\mathrm{NH}_{3} \dagger$}

\author{
Shuangshuang Lai, Dongmei Meng, Wangcheng Zhan, ${ }^{\star}$ Yun Guo, Yanglong Guo, \\ Zhigang Zhang and Guanzhong Lu*
}

Cu/ZSM-5 and Ce doped Cu/ZSM-5 catalysts were prepared by the incipient-wetness-impregnation method, and the effect of Ce doping on the structure and the catalytic performance of the Cu/ZSM-5 catalyst was investigated in detail for the selective catalytic reduction (SCR) of $\mathrm{NO}$ with $\mathrm{NH}_{3}$. The results showed that the addition of $\mathrm{Ce}$ can markedly broaden the operation temperature window of the Cu/ZSM-5 catalyst for $\mathrm{NH}_{3}-\mathrm{SCR}$ and enhance its $\mathrm{H}_{2} \mathrm{O}$ and $\mathrm{SO}_{2}$ resistance. The presence of Ce promoted an enrichment of copper species (isolated $\mathrm{Cu}^{2+}$ ions and $\mathrm{CuO}$ nanoparticles) on the catalyst surface and the increase in the Lewis acid sites on the surface of the Cu/ZSM- 5 catalyst, and strengthened the redox property of the Cu/ZSM-5 catalyst. As a result, Ce-doped Cu/ZSM-5 catalyst possessed the high adsorption ability of $\mathrm{NH}_{3}$ and nitrite/nitrate, which is propitious to the increase in the reactivity of the Ce-doped Cu/ZSM-5 catalyst. In situ DRIFTS results indicated that the $\mathrm{NH}_{3}-\mathrm{SCR}$ reaction on the $\mathrm{Cu} / Z \mathrm{SM}-5$ catalyst and $\mathrm{Ce}_{1}-\mathrm{Cu}_{4} / Z S M-5$ catalysts definitely followed LangmuirHinshelwood mechanisms, and bridged nitrates and bidentate nitrates were the active intermediate. However, Eley-Rideal mechanism can't be confirmed over the Cu/ZSM-5 and $\mathrm{Ce}_{1}-\mathrm{Cu}_{4} / \mathrm{ZSM}-5$ catalysts.

\section{Introduction}

Nitrogen oxides $\left(\mathrm{NO}_{x}\right)$ originated from various combustion processes are major air pollutants, which are very harmful to human health, due to the formation of photochemical smog, acid rain, ozone depletion and greenhouse effects. The selective catalytic reduction of $\mathrm{NO}_{x}$ with ammonia $\left(\mathrm{NH}_{3}-\mathrm{SCR}\right)$ in the presence of excess oxygen has been considered as one of the best available approaches to control the emission of $\mathrm{NO}_{x}$ produced from the stationary sources and the diesel vehicle. $\mathrm{V}_{2} \mathrm{O}_{5}-\mathrm{WO}_{3}\left(\mathrm{MoO}_{3}\right) / \mathrm{TiO}_{2}$ behaves the high activity and selectivity of $\mathrm{NH}_{3}$-SCR and has been the most widely used in industry. ${ }^{1}$ However, there are still some inevitable problems, such as the narrow working temperature window $\left(300-400{ }^{\circ} \mathrm{C}\right)$, the toxicity of vanadium species, ${ }^{2}$ and the low $\mathrm{N}_{2}$ selectivity at high temperatures. ${ }^{3}$ Therefore, it is necessary to develop vanadiumfree catalysts with high SCR activity.

In recent years, the zeolite-based catalysts are considered to be a practical solution for reducing the exhaust pollutants from

Key Laboratories for Advanced Materials, Research Institute of Industrial Catalysis, East China University of Science and Technology, 130 Meilong Road, Shanghai 200237, China. E-mail: gzhlu@ecust.edu.cn; zhanwc@ecust.edu.cn; Fax: +86-2164252923

$\dagger$ Electronic supplementary information (ESI) available. See DOI: $10.1039 / \mathrm{c} 5 \mathrm{ra} 12505 \mathrm{~g}$ diesel engines, and exhibit the high activities and good stability at high temperatures, ${ }^{4,5}$ especially the Cu/ZSM-5 catalyst due to its superior SCR activity and $\mathrm{N}_{2}$ selectivity in a wide temperature range. ${ }^{6}$ However, previous researches indicated that the $\mathrm{Cu}$ / ZSM-5 catalyst did not possess a high SCR activity at high temperature. ${ }^{7}$ With respect to monometallic copper loaded catalysts, it is difficult to enhance its SCR activity simply by increasing the copper content in the Cu/ZSM-5 catalyst. This is because a high content of copper inevitably leads to agglomeration of the copper species and formation of large copper oxide particles, ${ }^{8}$ which would enhance the oxidation of $\mathrm{NH}_{3}$ and narrow the temperature window. It has been determined that the optimal content of copper in the Cu/ZSM-5 catalyst is within 3-4 wt\%. ${ }^{9}$

Ceria has been studied extensively as an oxygen reservoir, which can store and release oxygen by the redox cycle between $\mathrm{Ce}^{3+}$ and $\mathrm{Ce}^{4+}$ under oxidizing and reducing conditions. ${ }^{\mathbf{1 0 - 1 2}}$ Many Ce doped catalysts were studied extensively and used in the various reactions, including $\mathrm{CeO}_{2}-\mathrm{MnO}_{x},{ }^{\mathbf{1 0 , 1 3}}$ was reported that Ce-Cu/ZSM-5 catalyst was used for $\mathrm{NH}_{3}$ SCR reaction. Pang et al. ${ }^{\mathbf{1 7}}$ reported that adding Ce into $\mathrm{Cu}$ / ZSM-5 monolithic catalyst could obviously improve its activity and hydrothermal stability by stabilizing the dispersion of $\mathrm{CuO}$ and suppressing the formation of bulk-type $\mathrm{CuO}$ crystallites during hydrothermal treatment. Dou et al. ${ }^{18}$ also $\mathrm{CeWO}_{x},{ }^{14} \mathrm{Ce}-\mathrm{Mn} / \mathrm{ZSM}-5,{ }^{11}$ and Ce-Cu/ZSM-5. ${ }^{15,16}$ Recently, it 
confirmed that Ce doping improved the redox properties of the $\mathrm{Cu}-\mathrm{Ce} / \mathrm{ZSM}-5$ catalyst, due to the higher valence of copper and mobility of lattice oxygen than those of Cu/ZSM-5 catalyst. But little attention has been paid to the effect of Ce doping on the acid sites, surface species and adsorption property of $\mathrm{Ce}-\mathrm{Cu} / \mathrm{ZSM}-5$ catalysts. And the surface reaction mechanism over the Ce-Cu/ZSM-5 catalyst for the $\mathrm{NH}_{3}-\mathrm{SCR}$ reaction and the role of Ce on the catalytic cycle has not been investigated.

Herein, we try to solve two problems for Ce doped Cu/ZSM-5 catalysts, the promotional role of Ce and the surface reaction mechanism over the Ce-Cu/ZSM-5 catalyst for the $\mathrm{NH}_{3}$-SCR reaction, including the effect of Ce doping on the $\mathrm{SO}_{2}$ resistance and water resistance. These research results will certainly be useful for the further development of the zeolite catalysts for the $\mathrm{NH}_{3}$-SCR reaction.

\section{Experimental}

\subsection{Preparation of catalysts}

A series of $\mathrm{Ce}_{x}-\mathrm{Cu}_{4} / \mathrm{ZSM}-5$ catalysts with copper content of 4 wt $\%$ and variable content of cerium were prepared by an improved incipient-wetness-impregnation method. H-ZSM-5 with $\mathrm{Si} / \mathrm{Al}$ atomic ratio of 18 was supplied by Nankai University, Tianjin, China. In a typical process, the required amount of an aqueous solution of $\mathrm{Cu}\left(\mathrm{NO}_{3}\right)_{2} \cdot 3 \mathrm{H}_{2} \mathrm{O}$ and $\mathrm{Ce}\left(\mathrm{NO}_{3}\right)_{3} \cdot 6 \mathrm{H}_{2} \mathrm{O}$ was slowly dropped into the support under vigorous stirring at room temperature, and then ultrasonically treated for $1 \mathrm{~h}$. The content of copper in the catalysts was maintained at $4 \mathrm{wt} \%$, and the content of cerium was varied. The solid was dried at $120{ }^{\circ} \mathrm{C}$ for $12 \mathrm{~h}$ and calcined in air at $550{ }^{\circ} \mathrm{C}$ for $4 \mathrm{~h}$. The final catalysts were labeled as $\mathrm{Ce}_{x^{-}}$ $\mathrm{Cu}_{4} / \mathrm{ZSM}-5$ ( $x$ denotes the weight ratio of Ce/H-ZSM-5, $x=$ $0.5,1,2 \mathrm{wt} \%)$.

The $\mathrm{Cu}_{4} / \mathrm{ZSM}-5$ catalyst was also prepared with the same procedure as $\mathrm{Ce}_{x}-\mathrm{Cu}_{4} / \mathrm{ZSM}-5$, but no $\mathrm{Ce}\left(\mathrm{NO}_{3}\right)_{3} \cdot 6 \mathrm{H}_{2} \mathrm{O}$ was added in the synthesis solution.

\subsection{Catalyst characterization}

The XRD patterns were recorded on a Brook/D8 diffractometer with CuK $\alpha$ Radiation $(\lambda=0.154056 \mathrm{~nm})$ in the $2 \theta$ range of $5-$ $60^{\circ}$. The morphologies of the catalysts were investigated by field emission scanning electron microscopy (FE-SEM) on a Hitachi S-4800 instrument operated at the beam energy of 15 $\mathrm{kV}$. The $\mathrm{N}_{2}$ adsorption-desorption isotherms were measured on a Quantachrome NOVA1200 surface area at $-196{ }^{\circ} \mathrm{C}$. Prior to the measurements, all samples were degassed at $180{ }^{\circ} \mathrm{C}$ until a stable vacuum of $c a .5$ mTorr was reached. The surface areas of the samples were calculated by Brunauer-EmmettTeller (BET) method. The pore size distribution were calculated from the desorption branch using the Barrett-JoynerHalenda (BJH) method. The XPS spectra were recorded on a Thermo ESCALAB 250 spectrometer with a monochromatized AlK $\alpha$ X-ray source $(1486.6 \mathrm{eV})$ and a passing energy of $25 \mathrm{eV}$. C1s (binding energy $284.6 \mathrm{eV}$ ) of adventitious carbon was used as the reference.
Py-IR spectra of samples were analyzed by a Nicolet 5700 FTIR spectrometer. The samples $(13 \mathrm{mg})$ was heated at $400{ }^{\circ} \mathrm{C}$ under vacuum for $2 \mathrm{~h}$, and cooled to $200{ }^{\circ} \mathrm{C}$ when pyridine was chemisorbed for $10 \mathrm{~min}$. After this step, the sample was evacuated and analyzed by FTIR.

Temperature-programmed desorption of $\mathrm{NH}_{3}\left(\mathrm{NH}_{3}\right.$-TPD) was carried out on a PX200 apparatus (Tianjin Pengxiang Technology Ltd. China) with a thermal conductivity detector (TCD). $50 \mathrm{mg}$ of the sample was filled into the quartz reactor and pretreated at $500{ }^{\circ} \mathrm{C}$ in a flow of $\mathrm{N}_{2}\left(50 \mathrm{~mL} \mathrm{~min}^{-1}\right)$ for $1 \mathrm{~h}$. After being cooled down to room temperature, the sample was exposed to a flow of $10 \% \mathrm{NH}_{3} / \mathrm{N}_{2}\left(50 \mathrm{~mL} \mathrm{~min}^{-1}\right)$ for $0.5 \mathrm{~h}$. Then the sample was flushed by $\mathrm{N}_{2}\left(50 \mathrm{~mL} \mathrm{~min}^{-1}\right)$ for $1 \mathrm{~h}$ and $\mathrm{NH}_{3}$ TPD was carried out by heating the sample in $\mathrm{N}_{2}\left(50 \mathrm{~mL} \mathrm{~min}^{-1}\right)$ from room temperature to $500{ }^{\circ} \mathrm{C}$ at $10{ }^{\circ} \mathrm{C} \mathrm{min}^{-1}$.

NO-TPD was carried out on the custom-made equipment with a $\mathrm{NO}_{x}$ analyzer (Thermo Fisher Model 42i-HL NO- $\mathrm{NO}_{x}$ chemiluminescence analyzer) as detector. The sample was

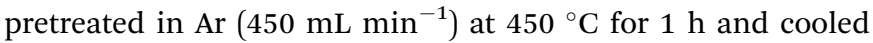
down to room temperature. Then the sample was exposed to a flow of $500 \mathrm{ppm} \mathrm{NO/Ar}\left(300 \mathrm{~mL} \mathrm{~min}^{-1}\right)$ for $1 \mathrm{~h}$ to reach saturated adsorption of NO on the sample, followed by $\operatorname{Ar}(300$ $\mathrm{mL} \mathrm{min}^{-1}$ ) purging for $1 \mathrm{~h}$. Finally, NO-TPD was carried out by heating the sample in $\mathrm{Ar}\left(300 \mathrm{~mL} \mathrm{~min}^{-1}\right)$ from room temperature to $450{ }^{\circ} \mathrm{C}$ at $10{ }^{\circ} \mathrm{C} \mathrm{min}^{-1}$.

Temperature-programmed reduction with $\mathrm{H}_{2}\left(\mathrm{H}_{2}\right.$-TPR) was performed in a conventional flow apparatus. $100 \mathrm{mg}$ of the sample was used. A flow of $5 \% \mathrm{H}_{2} / \mathrm{N}_{2}\left(40 \mathrm{~mL} \mathrm{~min}^{-1}\right)$ was passed through the catalyst bed at $10{ }^{\circ} \mathrm{C} \min ^{-1}$ from 30 to $600{ }^{\circ} \mathrm{C}$. The consumption of hydrogen was monitored by a thermal conductivity detector (TCD).

The in situ DRIFT measurements were performed on a Nicolet 6700 FT-IR spectrometer with a MCT detector. The sample was pretreated at $500{ }^{\circ} \mathrm{C}$ in $\mathrm{Ar}$ for $1 \mathrm{~h}$, and then cooled to $150{ }^{\circ} \mathrm{C}$ in Ar. The background spectra were recorded at the different temperatures during the cooling, and background was subtracted from sample spectra accordingly.

\subsection{Catalytic activity testing}

The catalytic activities of the $\mathrm{Ce}_{x}-\mathrm{Cu}_{4} / \mathrm{ZSM}-5$ catalysts for $\mathrm{NH}_{3}$ SCR in excess oxygen were investigated in a fixed-bed quartz reactor $(\Phi 6 \mathrm{~mm} \times 300 \mathrm{~mm}) .200 \mathrm{mg}$ of the catalyst (20-40 mesh) was used. The reactant gas was composed of $500 \mathrm{ppm}$ $\mathrm{NO}, 500 \mathrm{ppm} \mathrm{NH}_{3}, 5$ vol\% $\mathrm{O}_{2}, 2$ vol\% $\mathrm{H}_{2} \mathrm{O}$ (when used), $50 \mathrm{ppm}$ $\mathrm{SO}_{2}$ (when used) and balanced Ar. The gas hourly space velocity (GHSV) was $55000 \mathrm{~h}^{-1}$. The concentrations of $\mathrm{NO}$ and $\mathrm{NO}_{2}$ remained in the product were analysed by a Thermo Fisher NO$\mathrm{NO}_{x}$-chemiluminescence analyzer. To avoid modest errors caused by the oxidation of ammonia in the converter of $\mathrm{NO} / \mathrm{NO}_{x}$ analyzer, an ammonia trap containing phosphoric acid solution was installed prior to the chemiluminescence detector. $\mathrm{NO}_{x}$ conversion $X\left(\mathrm{NO}_{x}\right)$ was calculated as follows:

$$
X\left(\mathrm{NO}_{x}\right)=\frac{\left[\mathrm{NO}_{x}\right]_{\text {in }}-\left[\mathrm{NO}_{x}\right]_{\text {out }}}{\left[\mathrm{NO}_{x}\right]_{\text {in }}} \times 100 \%
$$




\section{Results and discussion}

\subsection{Catalytic performance for $\mathrm{NH}_{3}$-SCR activity}

The catalytic activities of the $\mathrm{Cu}_{4} / \mathrm{ZSM}-5$ and $\mathrm{Ce}_{x}-\mathrm{Cu}_{4} / \mathrm{ZSM}-5$ catalysts for the $\mathrm{NH}_{3}$-SCR reaction are shown in Fig. 1. The H-ZSM-5 catalyst exhibited a very low activity, over which the maximum $\mathrm{NO}_{x}$ conversion is only $80 \%$ at $425{ }^{\circ} \mathrm{C}$. The $\mathrm{Cu}_{4} / \mathrm{ZSM}-5$ catalyst has a high catalytic activity, and the $\mathrm{NO}_{x}$ conversion of above $90 \%$ was obtained at $195-435{ }^{\circ} \mathrm{C}$.

When cerium was added to $\mathrm{Cu}_{4} / \mathrm{ZSM}-5$, the catalytic activity of $\mathrm{Cu}_{4} / \mathrm{ZSM}-5$ toward $\mathrm{NH}_{3}$-SCR reaction was significantly improved, especially at the high temperature. For example, when the $\mathrm{Ce}_{1}-\mathrm{Cu}_{4} / \mathrm{ZSM}-5$ catalyst was used, the temperature window of more than $90 \% \mathrm{NO}_{x}$ conversion was $185-470{ }^{\circ} \mathrm{C}$; while for the $\mathrm{Ce}_{2}-\mathrm{Cu}_{4} / \mathrm{ZSM}-5$ and $\mathrm{Ce}_{0.5}-\mathrm{Cu}_{4} / \mathrm{ZSM}-5$ catalysts, their window were $180-460^{\circ} \mathrm{C}$ and $175-450{ }^{\circ} \mathrm{C}$, respectively. The results clearly demonstrate that comparing with the operation window of $\mathrm{Cu}_{4} / \mathrm{ZSM}-5$ catalyst, adding an appropriate amount of $\mathrm{Ce}$ in this catalyst can broaden the operation window about $45{ }^{\circ} \mathrm{C}$. Furthermore, the amount of Ce obviously affects the $\mathrm{NH}_{3}$ SCR activity of the $\mathrm{Ce}_{x}-\mathrm{Cu}_{4} / \mathrm{ZSM}-5$ catalyst at the high temperature, while this influence is faint at the low temperature.

On the other hand, both the $\mathrm{Cu}_{4} / \mathrm{ZSM}-5$ and $\mathrm{Ce}_{1}-\mathrm{Cu}_{4} / \mathrm{ZSM}-5$ catalysts behaved the high stability after the $\mathrm{NH}_{3}$-SCR reaction. As shown in Fig. $\mathrm{S} 1, \dagger$ the $\mathrm{NH}_{3}$-SCR activities of the $\mathrm{Cu}_{4} / \mathrm{ZSM}-5$ and $\mathrm{Ce}_{1}-\mathrm{Cu}_{4} / \mathrm{ZSM}-5$ catalysts on the second run are almost the same as those on the first run.

\subsection{Physicochemical properties of catalysts}

Fig. 2 shows the XRD patterns of $\mathrm{H}-\mathrm{ZSM}-5, \mathrm{Cu}_{4} / \mathrm{ZSM}-5$ and $\mathrm{Ce}_{x^{-}}$ $\mathrm{Cu}_{4} / \mathrm{ZSM}-5$ catalysts. All the samples exhibit the typical diffraction peaks of ZSM-5 zeolite at $2 \theta=7.9^{\circ}, 8.8^{\circ}, 23.1^{\circ}$ and $23.8^{\circ}$, which represent the (011), (020), (051) and (033) planes, respectively. ${ }^{19}$ Comparing with the XRD spectrum of $\mathrm{H}-\mathrm{ZSM}-5$, the XRD spectra of $\mathrm{Cu}_{4} / \mathrm{ZSM}-5$ and $\mathrm{Ce}_{x}-\mathrm{Cu}_{4} / \mathrm{ZSM}-5$ catalysts

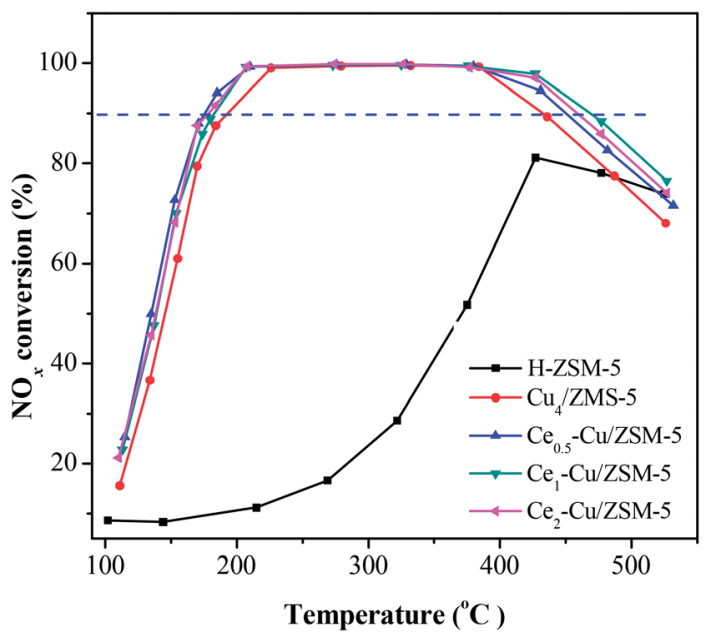

Fig. $1 \mathrm{NO}_{x}$ conversion as a function of the reaction temperature over $\mathrm{Cu} / \mathrm{ZSM}-5$ and $\mathrm{Ce}_{x}-\mathrm{Cu}_{4} / \mathrm{ZSM}-5$ catalysts for the $\mathrm{NH}_{3}-\mathrm{SCR}$ reaction (Reaction conditions: $0.2 \mathrm{~g}$ catalyst, the reactant gas of $500 \mathrm{ppm} \mathrm{NO/}$ $500 \mathrm{ppm} \mathrm{NH} / 5 \% \mathrm{O}_{2} /$ Ar balanced, GHSV $=55000 \mathrm{~h}^{-1}$ ).

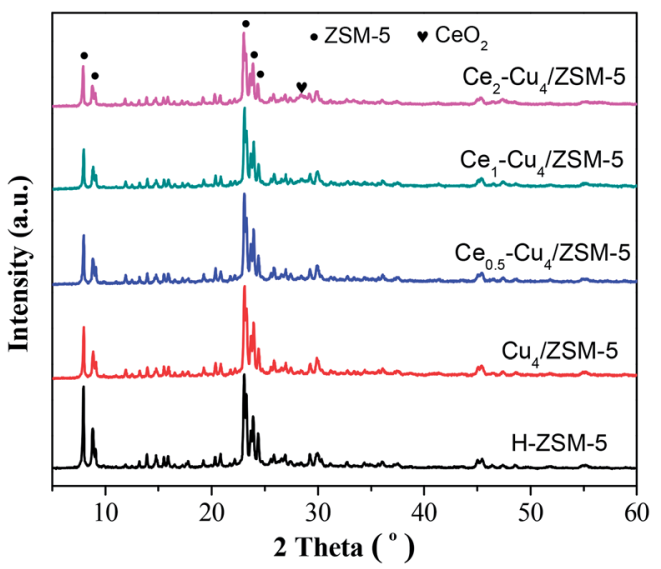

Fig. 2 Wide-angle XRD patterns of pure $\mathrm{H}-\mathrm{ZSM}-5, \mathrm{Cu}_{4} / \mathrm{ZSM}-5$ and $\mathrm{Ce}_{x}-\mathrm{Cu}_{4} / \mathrm{ZSM}-5$ catalysts

were changed inconspicuously, which indicates that the structure of zeolite support remains intact after adding $\mathrm{Cu}$ and $\mathrm{Ce}$. On the other hand, the diffraction peaks of $\mathrm{CuO}$ are not detected for all catalysts, showing that the copper species are well dispersed on the surface of the ZSM-5 support, or aggregated crystallites are too small to be detected by XRD. Similarly, the diffraction peaks of $\mathrm{CeO}_{2}$ are not also detected for the $\mathrm{Ce}_{x}-$ $\mathrm{Cu}_{4} / \mathrm{ZSM}-5$ catalysts with low $\mathrm{Ce}$ content. However, with increasing the Ce content to $2.0 \mathrm{wt} \%$, the very weak diffraction peak of $\mathrm{CeO}_{2}$ can be observed $\left(2 \theta=28.2^{\circ}\right)$ for the $\mathrm{Ce}_{2}-\mathrm{Cu}_{4} / \mathrm{ZSM}$ 5 catalyst, indicating the formation of $\mathrm{CeO}_{2}$ crystallites on the surface of the $\mathrm{Ce}_{2}-\mathrm{Cu}_{4} / \mathrm{ZSM}-5$ catalyst.

Fig. 3 shows the SEM images of $\mathrm{H}-\mathrm{ZSM}-5, \mathrm{Cu}_{4} / \mathrm{ZSM}-5$ and $\mathrm{Ce}_{1}-\mathrm{Cu}_{4} / \mathrm{ZSM}-5$ catalysts. The results show that, H-ZSM-5 exhibits the schistose and irregular morphology, and after the addition of $\mathrm{Cu}$ and $\mathrm{Ce}$, the morphologies of $\mathrm{Cu}_{4} / \mathrm{ZSM}-5$ and $\mathrm{Ce}_{x^{-}}$ $\mathrm{Cu}_{4} / \mathrm{ZSM}-5$ catalysts are virtually unchanged. The BET surface area, average pore diameter and micro-pore volume are listed in Table 1 . It can be seen that adding $\mathrm{Cu}$ leads to the decrease in

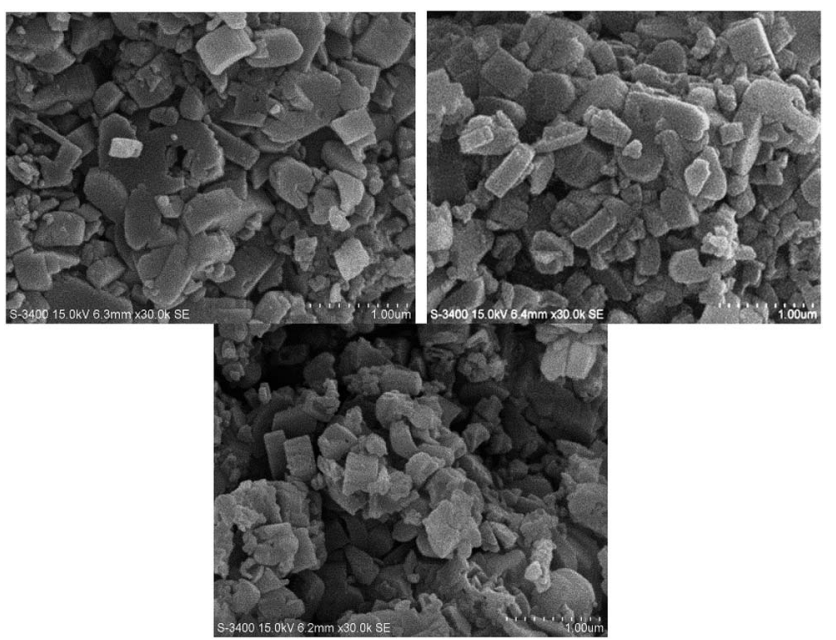

Fig. 3 SEM images of pure $\mathrm{H}-\mathrm{ZSM}-5$ (top left), $\mathrm{Cu}_{4} / \mathrm{ZSM}-5$ (top right) and $\mathrm{Ce}_{1}-\mathrm{Cu}_{4} / \mathrm{ZSM}-5$ (bottom). 
Table 1 BET surface area $\left(S_{\mathrm{BET}}\right)$ and surface atom concentrations of the $\mathrm{Cu}_{4} / \mathrm{ZSM}-5$ and $\mathrm{Ce}_{1}-\mathrm{Cu}_{4} / \mathrm{ZSM}-5$ catalysts derived from XPS data

\begin{tabular}{|c|c|c|c|c|c|c|c|}
\hline Sample & $S_{\text {BET }}\left(\mathrm{m}^{2} \mathrm{~g}^{-1}\right)$ & $\begin{array}{l}\text { Average pore } \\
\text { diameter }(\mathrm{nm})\end{array}$ & $\begin{array}{l}\text { Micro-pore } \\
\text { volume }\left(\mathrm{cm}^{3} \mathrm{~g}^{-1}\right)\end{array}$ & $\begin{array}{l}\text { Isolated } \\
\mathrm{Cu}^{2+} / \mathrm{CuO}^{a}\end{array}$ & \multicolumn{3}{|l|}{ Surface composition (at\%) } \\
\hline $\mathrm{Cu}_{4} / \mathrm{ZSM}-5$ & 280 & 1.6 & 0.12 & 0.239 & $1.59(0.31 / 1.28)$ & - & 63.2 \\
\hline $\mathrm{Ce}_{1}-\mathrm{Cu}_{4} / \mathrm{ZSM}-5$ & 268 & 1.6 & 0.12 & 0.247 & $1.97(0.39 / 1.58)$ & 0.25 & 62.8 \\
\hline
\end{tabular}

BET surface area, average pore diameter and micro-pore volume, which can be attributed to the fact that copper species cover the external surface of H-ZSM-5, blocking many zeolite channels. After the addition of Ce into the $\mathrm{Cu}_{4} / \mathrm{ZSM}-5$ catalyst, BET surface area was decreased slightly, while average pore diameter and micro-pore volume remained unchanged.

Fig. 4 shows XPS Cu2p spectra of $\mathrm{Cu}_{4} / \mathrm{ZSM}-5$ and $\mathrm{Ce}_{1}-\mathrm{Cu}_{4} /$ ZSM- 5 catalysts. The $\mathrm{Cu}_{4} / \mathrm{ZSM}-5$ catalyst has two main peaks at $\mathrm{BE}=933.6 \mathrm{eV}$ and $953.0 \mathrm{eV}$ in its XPS Cu2p spectra, which are attributed to $\mathrm{Cu} 2 \mathrm{p} 3 / 2$ and $\mathrm{Cu} 2 \mathrm{p} 1 / 2$, respectively. The Cu2p $3 / 2$ peaks can be deconvoluted to two peaks, and the peaks at 933.4 eV represent the agglomerated $\mathrm{CuO}$ nanoparticles on the surface of catalysts, and the one at $\mathrm{BE}=935.2 \mathrm{eV}$ is attributed to isolated $\mathrm{Cu}^{2+}$ ion coordinated to superficial oxygen atoms of zeolite. ${ }^{18,20}$ Since the diffraction peaks of $\mathrm{CuO}$ species could not be observed in the XRD spectra, these CuO crystallites' size should be lower than $3 \mathrm{~nm}$.

Table 1 shows the surface atom concentrations of $\mathrm{Cu}_{4} / \mathrm{ZSM}-5$ and $\mathrm{Ce}_{1}-\mathrm{Cu}_{4} / \mathrm{ZSM}-5$ catalysts. It can be seen that surface $\mathrm{Cu}$ amount increases with the addition of $\mathrm{Ce}$ in the $\mathrm{Cu}_{4} / \mathrm{ZSM}-5$ catalyst, indicating that the presence of Ce can help to the enrichment of $\mathrm{Cu}$ on the $\mathrm{Cu}_{4} / \mathrm{ZSM}-5$ surface. According to the peak area ratio of (isolated $\mathrm{Cu}^{2+}$ ions)/(CuO crystallites) in XPS

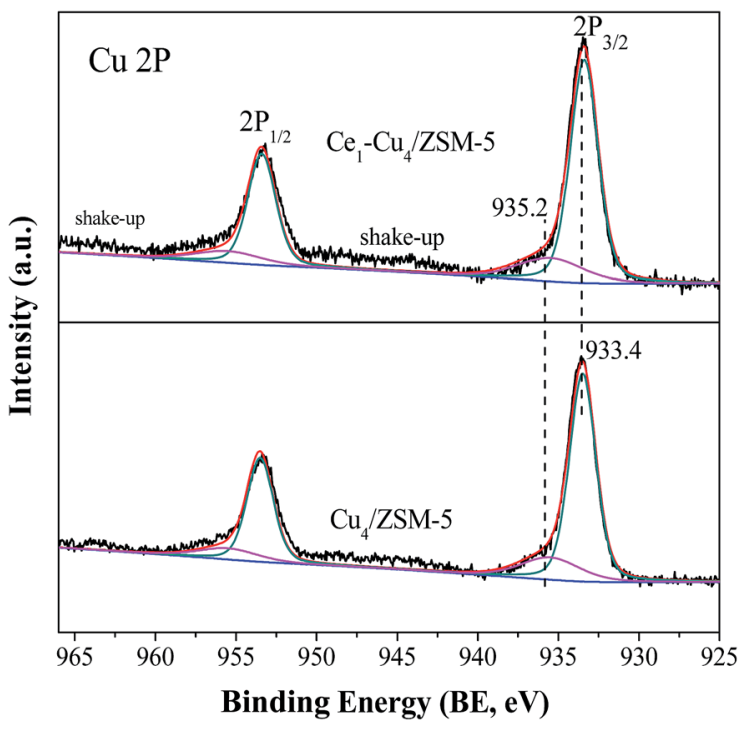

Fig. 4 XPS Cu2p spectra of $\mathrm{Cu}_{4} / Z S M-5$ and $\mathrm{Ce}_{1}-\mathrm{Cu}_{4} / Z S M-5$ catalysts. spectra, the amounts of isolated $\mathrm{Cu}^{2+}$ ions and $\mathrm{CuO}$ crystallites on the surface of $\mathrm{Cu}_{4} / \mathrm{ZSM}-5$ and $\mathrm{Ce}_{1}-\mathrm{Cu}_{4} / \mathrm{ZSM}-5$ catalysts were calculated (Table 1 ). The results show that $\mathrm{CuO}$ crystallites are predominant on the surface of both $\mathrm{Cu}_{4} / \mathrm{ZSM}-5$ and $\mathrm{Ce}_{1}-\mathrm{Cu}_{4} /$ ZSM- 5 catalysts with a high Cu content, which is consistent with the reported results. ${ }^{20}$ Furthermore, the surface concentrations of isolated $\mathrm{Cu}^{2+}$ ions and $\mathrm{CuO}$ crystallites over the $\mathrm{Ce}_{1}-\mathrm{Cu}_{4} /$ ZSM- 5 catalyst are higher than that over the $\mathrm{Cu}_{4} / \mathrm{ZSM}-5$ catalyst, because of the increase of the surface $\mathrm{Cu}$ atoms after Ce addition in the $\mathrm{Cu}_{4} / \mathrm{ZSM}-5$ catalyst.

Wang et al. ${ }^{21}$ thought both $\mathrm{CuO}$ nanoparticles and isolated $\mathrm{Cu}^{2+}$ ion in $\mathrm{Cu} / \mathrm{SAPO}-34$ were active sites for the $\mathrm{NH}_{3}$-SCR reaction. Furthermore, it is revealed that the $\mathrm{CuO}$ nanoparticles catalyzes the oxidation of $\mathrm{NO}$ to $\mathrm{NO}_{2}$, and this favors the reduction of $\mathrm{NO}$ at lower temperature due to the facilitation of the "fast SCR" process, while isolated $\mathrm{Cu}^{2+}$ ions help to the high NO conversion at high temperature. Therefore, when adding Ce in the $\mathrm{Cu}_{4} / \mathrm{ZSM}-5$ catalyst, the increase in the surface concentrations of both isolated $\mathrm{Cu}^{2+}$ ions and $\mathrm{CuO}$ nanoparticles can improve the activity of the $\mathrm{Cu}_{4} / \mathrm{ZSM}-5$ catalyst.

Fig. 5 shows the UV-Vis absorption spectra of $\mathrm{H}-\mathrm{ZSM}-5, \mathrm{Cu}_{4} /$ ZSM-5 and $\mathrm{Ce}_{1}-\mathrm{Cu}_{4} / \mathrm{ZSM}-5$ catalysts. H-ZSM-5 exhibits the adsorption bands at about 210 and $280 \mathrm{~nm}$. For $\mathrm{Cu}_{4} / \mathrm{ZSM}-5$, a band at $258 \mathrm{~nm}$ and a broad band centered at $750 \mathrm{~nm}$ between 550 and $800 \mathrm{~nm}$ appeared. The former can be assigned to $\mathrm{O} \rightarrow \mathrm{Cu}$ transitions of isolated $\mathrm{Cu}^{2+}$ ions in coordination with lattice oxygen, and the latter can be assigned to $\mathrm{d}-\mathrm{d}$ transitions

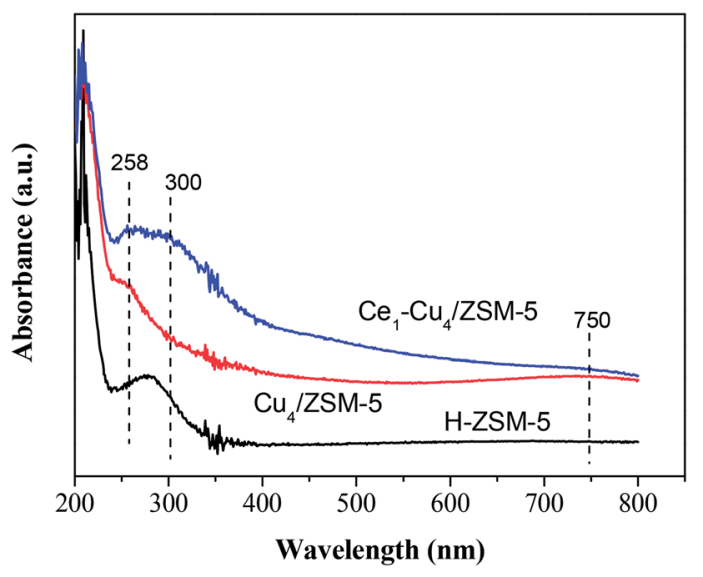

Fig. 5 UV-Vis spectra of $\mathrm{H}-\mathrm{ZSM}-5, \mathrm{Cu}_{4} / \mathrm{ZSM}-5$ and $\mathrm{Ce}_{1}-\mathrm{Cu}_{4} / \mathrm{ZSM}-5$ catalysts. 
of $\mathrm{Cu}^{2+}$ ions in a octahedrically coordinated environment due to dispersed $\mathrm{CuO}$ crystallites on the catalyst surface. ${ }^{22-24}$ When cerium was added to $\mathrm{Cu}_{4} / \mathrm{ZSM}-5$, a broad band centered at 300 nm appeared, which can be attributed to well-dispersed Ce species on the surface of catalyst (presumably in a tetracoordinated environment), which is confirmed by the XRD results. ${ }^{25}$ Meanwhile, the intensity of $258 \mathrm{~nm}$ band was increased compared with that in UV-Vis spectra of $\mathrm{Cu}_{4} / \mathrm{ZSM}-5$ catalyst, indicating the increase in the amount of isolated $\mathrm{Cu}^{2+}$ ions, which is consistent with the XPS results. On the contrary, it is difficult to quantify $\mathrm{CuO}$ crystallites on the catalyst surface because two bands centered at 300 and $750 \mathrm{~nm}$ overlap complexity.

\subsection{Temperature-programmed desorption}

Fig. 6 shows $\mathrm{NH}_{3}$-TPD profiles of the $\mathrm{H}-\mathrm{ZSM}-5, \mathrm{Cu}_{4} / \mathrm{ZSM}-5$ and $\mathrm{Ce}_{1}-\mathrm{Cu}_{4} / \mathrm{ZSM}-5$ catalysts in the temperature range of $100-500{ }^{\circ} \mathrm{C}$. Two desorption peaks at 200 and $410{ }^{\circ} \mathrm{C}$ can be observed for the $\mathrm{H}-\mathrm{ZSM}-5$ catalyst. The desorption peak at $200{ }^{\circ} \mathrm{C}$ is assigned to physisorbed $\mathrm{NH}_{3}$ or ammonium species, and the desorption peak at $410{ }^{\circ} \mathrm{C}$ is assigned to $\mathrm{NH}_{3}$ absorbed at the strong acid sites. ${ }^{26}$

After adding copper and cerium, the $\mathrm{NH}_{3}$-TPD profiles have been obviously changed. The desorption peak at $410{ }^{\circ} \mathrm{C}$ radically decreased for the $\mathrm{Cu}_{4} / \mathrm{ZSM}-5$ and $\mathrm{Ce}_{1}-\mathrm{Cu}_{4} / \mathrm{ZSM}-5$ catalysts. On the contrary, a shoulder peak at $306{ }^{\circ} \mathrm{C}$ presented for the $\mathrm{Cu}_{4} / \mathrm{ZSM}-5$ and $\mathrm{Ce}_{1}-\mathrm{Cu}_{4} / \mathrm{ZSM}-5$ catalysts. The reasons for this phenomena were because part of Brønsted acid protons were substituted by metal ion and strong Lewis acid sites were produced originating from metal oxide nanoparticles when adding $\mathrm{Cu}$ and/or Ce into the $\mathrm{H}-\mathrm{ZSM}-5$ catalyst. ${ }^{27,28}$ Compared with the $\mathrm{Cu}_{4} / \mathrm{ZSM}-5$ catalyst, the peak area at $306{ }^{\circ} \mathrm{C}$ is slightly larger for the $\mathrm{Ce}_{1}-\mathrm{Cu}_{4} / \mathrm{ZSM}-5$ catalyst, even if the specific surface area was considered, because the BET surface area $\left(268 \mathrm{~m}^{2} \mathrm{~g}^{-1}\right)$ of the former is less than that $\left(280 \mathrm{~m}^{2} \mathrm{~g}^{-1}\right)$ of the latter, indicating that the $\mathrm{Ce}_{1}-\mathrm{Cu}_{4} / \mathrm{ZSM}-5$ catalyst possessed the more strong acid sites than that on the $\mathrm{Cu}_{4} / \mathrm{ZSM}-5$ catalyst.

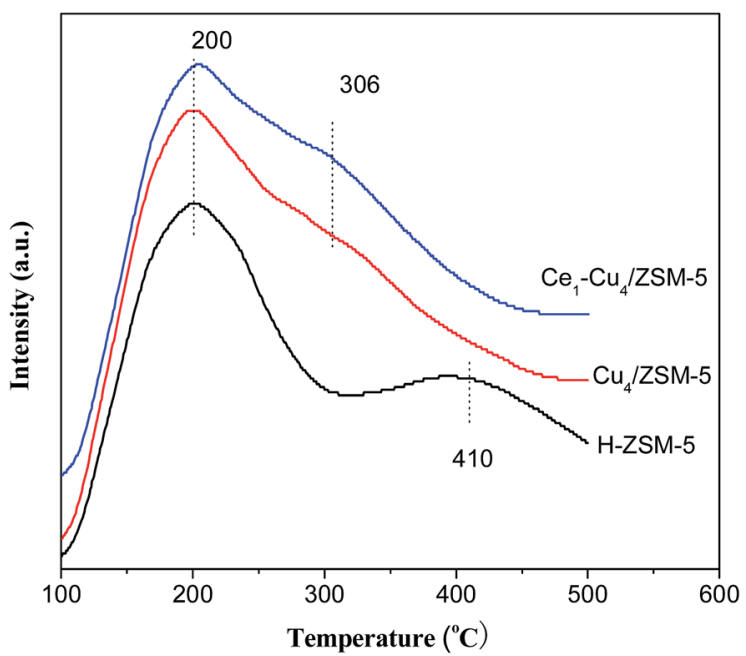

Fig. $6 \mathrm{NH}_{3}$-TPD profiles of $\mathrm{H}-\mathrm{ZSM}-5, \mathrm{Cu}_{4} / \mathrm{ZSM}-5$ and $\mathrm{Ce}_{1}-\mathrm{Cu}_{4} / \mathrm{ZSM}-$ 5 catalysts.
Fig. 7 shows IR spectra of adsorbed pyridine on H-ZSM-5, $\mathrm{Cu}_{4} / \mathrm{ZSM}-5$ and $\mathrm{Ce}_{1}-\mathrm{Cu}_{4} / \mathrm{ZSM}-5$ catalysts. The absorption bands at $1450 \mathrm{~cm}^{-1}$ and $1545 \mathrm{~cm}^{-1}$ are assigned to Lewis acid sites and Brønsted acid sites respectively, while the absorption band at $1490 \mathrm{~cm}^{-1}$ is assigned to both of them. The concentration of the Lewis acid sites (LA) and Brønsted acid sites (BA) were calculated from the intensity of the absorption bands at $1450 \mathrm{~cm}^{-1}$ and $1545 \mathrm{~cm}^{-1}$, and the results are shown in Table 2. It can be seen that the H-ZSM-5 catalyst mainly exhibited Brønsted acid sites. After adding copper, the amount of Brønsted acid sites markedly decreased due to the ion exchange during the preparation step. On the contrary, the amount of Lewis acid sites increased largely because of the presence of $\mathrm{Cu}^{2+}$ ions on the surface. Furthermore, compared with the H-ZSM-5 catalyst, the $\mathrm{Cu}_{4} / \mathrm{ZSM}-5$ catalyst possessed the higher amount of total acid sites. When adding cerium into the $\mathrm{Cu}_{4} / \mathrm{ZSM}-5$ catalyst, the amounts of both the Lewis acid sites and Brønsted acid sites were increased, leading to the higher amount of total acid sites, which is in accordance with the $\mathrm{NH}_{3}$-TPD results. It has been proved that Brønsted acid sites may not be required for activating ammonia, while Lewis acid sites plays an important role on the $\mathrm{NH}_{3}$-SCR process catalyzed by the zeolite catalyst. ${ }^{29}$ Therefore, the more Lewis acid sites over the $\mathrm{Ce}_{1}-\mathrm{Cu}_{4} / \mathrm{ZSM}-5$ catalyst might make the higher $\mathrm{NH}_{3}$-SCR activity of $\mathrm{Ce}_{1}-\mathrm{Cu}_{4} / \mathrm{ZSM}-5$ than the $\mathrm{Cu}_{4} / \mathrm{ZSM}-5$ catalyst.

The NO-TPD profiles of the catalysts are also shown in Fig. 8. Two obvious desorption peaks centered at 120 and $400{ }^{\circ} \mathrm{C}$ presented in the NO-TPD profile of the $\mathrm{Cu}_{4} / \mathrm{ZSM}-5$ catalyst. The desorption peak at $120{ }^{\circ} \mathrm{C}$ can be attributed to physisorbed $\mathrm{NO}_{x}$, and the desorption peak at $400{ }^{\circ} \mathrm{C}$ is due to the decomposition of nitrite and nitrate species with higher thermal stability. ${ }^{30}$ After adding Ce in the $\mathrm{Cu}_{4} / \mathrm{ZSM}-5$ catalyst, the desorption peak area at $400{ }^{\circ} \mathrm{C}$ increased remarkably, indicating that the addition of Ce can enhance the adsorption of nitrite and nitrate species on the surface of the $\mathrm{Cu}_{4} / \mathrm{ZSM}-5$ catalyst. In addition, the presence of $\mathrm{Ce}$ in this catalyst also improves the adsorption

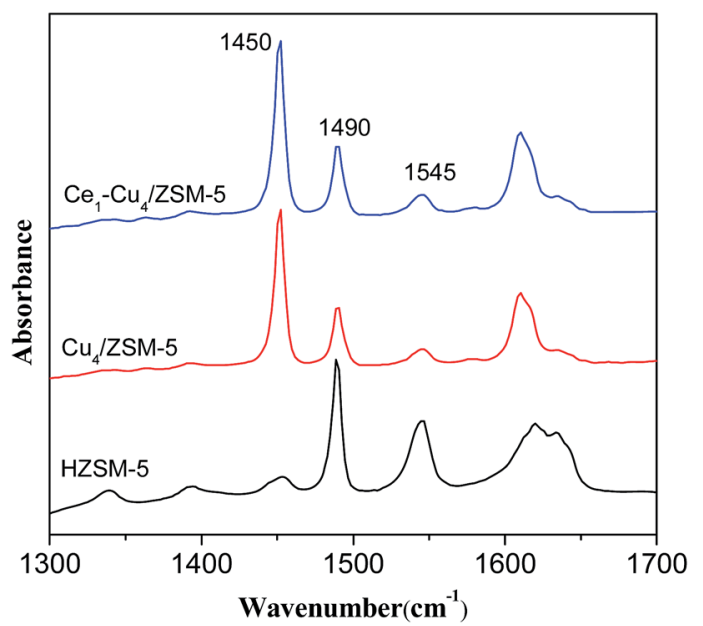

Fig. 7 IR spectra of adsorbed pyridine on $\mathrm{H}-\mathrm{ZSM}-5, \mathrm{Cu}_{4} / \mathrm{ZSM}-5$ and $\mathrm{Ce}_{1}-\mathrm{Cu}_{4} / \mathrm{ZSM}-5$ catalysts 
Table 2 Acidity of the H-ZSM-5, Cu $4 / Z S M-5$ and $\mathrm{Ce}_{1}-\mathrm{Cu}_{4} / \mathrm{ZSM}-5$ catalysts derived from IR spectra of adsorbed pyridine

\begin{tabular}{llll}
\hline Sample & $\begin{array}{l}\mathrm{LA}^{a} \\
\left(\mu \mathrm{mol} \mathrm{mg}{ }^{-1}\right)\end{array}$ & $\begin{array}{l}\mathrm{BA}^{b} \\
\left.(\mu \mathrm{mol} \mathrm{mg})^{-1}\right)\end{array}$ & $\begin{array}{l}\text { Total of acid } \\
\left.\text { sites }(\mu \mathrm{mol} \mathrm{mg})^{-1}\right)\end{array}$ \\
\hline $\mathrm{H}-\mathrm{ZSM}-5$ & 0.41 & 2.10 & 2.52 \\
$\mathrm{Cu}_{4} / \mathrm{ZSM}-5$ & 2.75 & 0.42 & 3.17 \\
$\mathrm{Ce}_{1}-\mathrm{Cu}_{4} / \mathrm{ZSM}-5$ & 3.08 & 0.54 & 3.62
\end{tabular}

${ }^{a}$ The Lewis acid sites. ${ }^{b}$ The Brønsted acid sites.

capacity and ability for NO at low temperature. As a result, more nitrite and nitrate species on the $\mathrm{Ce}_{1}-\mathrm{Cu}_{4} / \mathrm{ZSM}-5$ catalyst surface can participate the SCR reaction than that on the surface of the $\mathrm{Cu}_{4} / \mathrm{ZSM}-5$ catalyst, and the Ce doped catalyst can adsorb NO at lower temperature, resulting in the enhancement of the catalytic activity and the extension of the operation temperature window of the $\mathrm{Ce}_{1}-\mathrm{Cu}_{4} / \mathrm{ZSM}-5$ catalyst.

\section{$3.4 \quad \mathrm{H}_{2}$-TPR}

Fig. 9 shows $\mathrm{H}_{2}$-TPR profiles of $\mathrm{H}-\mathrm{ZSM}-5, \mathrm{Cu}_{4} / \mathrm{ZSM}-5$ and $\mathrm{Ce}_{1}-$ $\mathrm{Cu}_{4} / \mathrm{ZSM}-5$ catalysts. The H-ZSM-5 catalyst does not exhibit any reduction peaks. There are three reduction peaks at 213,245 and $330{ }^{\circ} \mathrm{C}$ in the TPR profile of the $\mathrm{Cu}_{4} / \mathrm{ZSM}-5$ catalyst. The reduction peak at $213{ }^{\circ} \mathrm{C}$ is attributed to the reduction of $\mathrm{CuO}$ nanoparticles dispersed on the ZSM-5 surface to $\mathrm{Cu}^{0}$, and the reduction peaks at 245 and $330{ }^{\circ} \mathrm{C}$ are assigned to the reduction of isolated $\mathrm{Cu}^{2+}$ to $\mathrm{Cu}^{0}$ through two steps. ${ }^{31}$ The reduction $\mathrm{Cu}^{2+}$ $\rightarrow \mathrm{Cu}^{+}$can occur at lower temperature, and the reduction $\mathrm{Cu}^{+}$ $\rightarrow \mathrm{Cu}^{0}$ only can carry out at higher temperature. For the $\mathrm{Ce}_{1}-$ $\mathrm{Cu}_{4} / \mathrm{ZSM}-5$ catalyst, there are also three reduction peaks, the peak at $330{ }^{\circ} \mathrm{C}$ shifted to a higher temperature of $350{ }^{\circ} \mathrm{C}$, and the reduction peak area at $213{ }^{\circ} \mathrm{C}$ was markedly increased comparing with the $\mathrm{Cu}_{4} / \mathrm{ZSM}-5$ catalyst, due to the high surface concentrations of $\mathrm{CuO}$ nanoparticles (Table 1). The results above show that adding $\mathrm{Ce}$ in the $\mathrm{Cu}_{4} / \mathrm{ZSM}-5$ catalyst can enhance its reducibility.

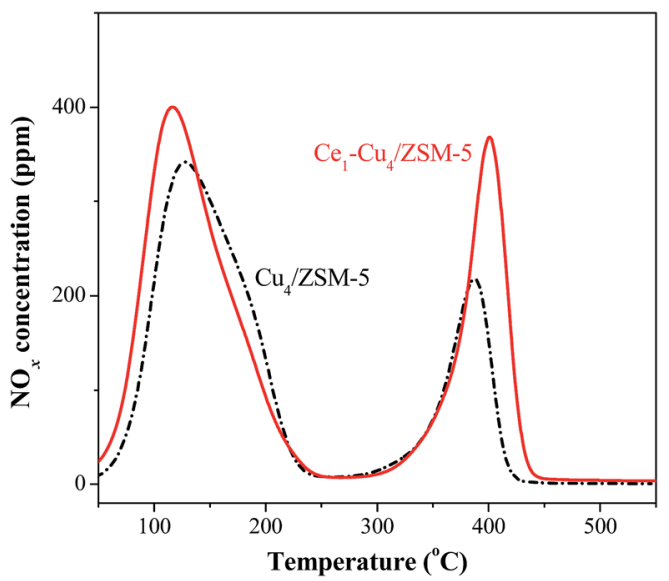

Fig. 8 NO-TPD profiles of the $\mathrm{Cu}_{4} / \mathrm{ZSM}-5$ and $\mathrm{Ce}_{1}-\mathrm{Cu}_{4} / \mathrm{ZSM}-5$ catalysts.

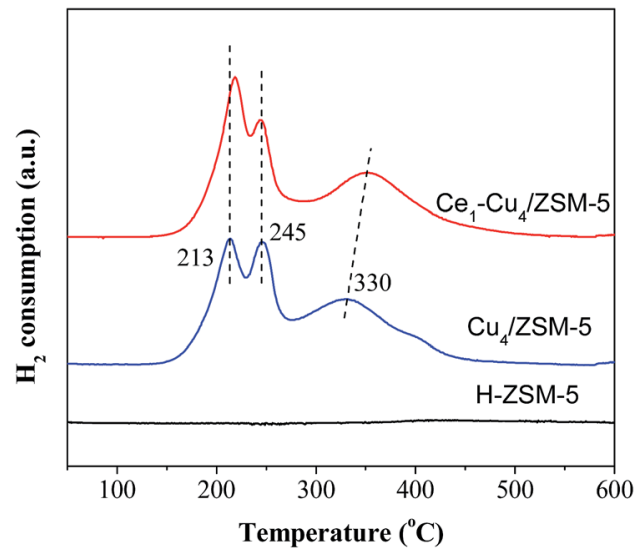

Fig. $9 \mathrm{H}_{2}$-TPR profiles of $\mathrm{H}-\mathrm{ZSM}-5, \mathrm{Cu}_{4} / \mathrm{ZSM}-5$ and $\mathrm{Ce}_{1}-\mathrm{Cu}_{4} / \mathrm{ZSM}-5$ catalysts.

\subsection{NO oxidation}

It is well known that the improvement of $\mathrm{NO}$ oxidation to $\mathrm{NO}_{2}$ over SCR catalysts can significantly promote its low temperature activity, due to the occurrence of the "fast SCR", $\mathrm{NO}+\mathrm{NO}_{2}+$ $2 \mathrm{NH}_{3} \rightarrow 2 \mathrm{~N}_{2}+3 \mathrm{H}_{2} \mathrm{O} .^{32}$ Therefore, the effect of adding Ce on the catalytic activity of the $\mathrm{Cu}_{4} / \mathrm{ZSM}-5$ catalyst for $\mathrm{NO}$ oxidation has been investigated. As shown in Fig. 10, for the NO oxidation at $<400{ }^{\circ} \mathrm{C}$, the activity of the $\mathrm{Ce}_{1}-\mathrm{Cu}_{4} / \mathrm{ZSM}-5$ catalyst is slightly higher than that of the $\mathrm{Cu}_{4} / \mathrm{ZSM}-5$ catalyst, due to the higher reducibility of the $\mathrm{Ce}_{1}-\mathrm{Cu}_{4} / \mathrm{ZSM}-5$ catalyst. At the high temperature, there is no difference of the catalytic activity of both catalysts for NO oxidation because of the equilibrium conversion.

\subsection{In situ DRIFT spectroscopy}

3.6.1 Adsorption of $\mathrm{NH}_{3}$ followed by introduction of $\mathrm{NO}+$ $\mathbf{O}_{2}$. Prior to $\mathrm{NH}_{3}$ adsorption, the catalyst was pretreated at $500{ }^{\circ} \mathrm{C}$ in the Ar flow of $50 \mathrm{~mL} \mathrm{~min}{ }^{-1}$ for $1 \mathrm{~h}$ and cooled to $150{ }^{\circ} \mathrm{C}$, and then the catalyst was exposed to the gas of $500 \mathrm{ppm} \mathrm{NH}_{3} / \mathrm{Ar}$

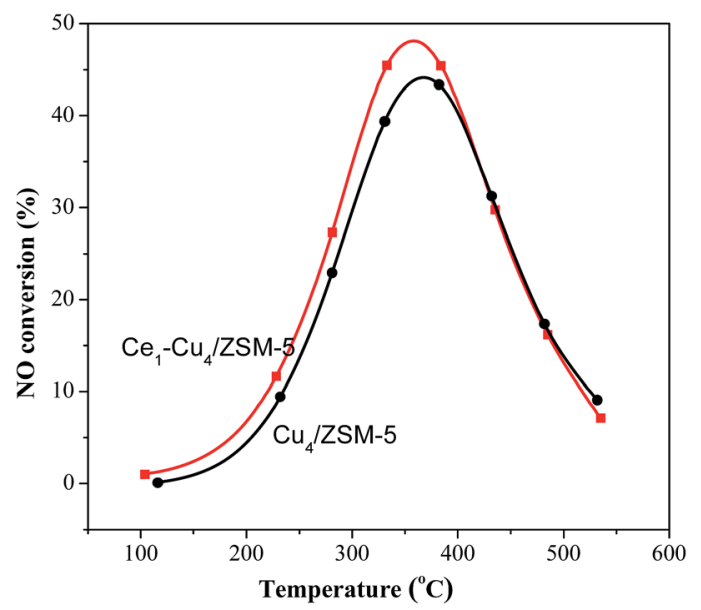

Fig. $10 \mathrm{NO}$ conversion in separate $\mathrm{NO}$ oxidation reaction over the $\mathrm{Cu}_{4} / \mathrm{ZSM}-5$ and $\mathrm{Ce}_{1}-\mathrm{Cu}_{4} / \mathrm{ZSM}-5$ catalysts. (Reaction conditions: $500 \mathrm{ppm} \mathrm{NO}+5$ vol\% $\mathrm{O}_{2} / \mathrm{Ar}$ balanced, total flow rate $300 \mathrm{~mL} \mathrm{~min}^{-1}$ ). 
$\left(50 \mathrm{~mL} \min ^{-1}\right)$ at $150{ }^{\circ} \mathrm{C}$, while in situ DRIFT spectra of the $\mathrm{Cu}_{4} /$ ZSM-5 (or Ce- $\mathrm{Cu}_{4} / \mathrm{ZSM}-5$ ) catalyst were taken for different times, and the DRIFT spectra of $\mathrm{NH}_{3}$ adsorbed on catalysts are presented in Fig. 11.

The bands at 1159 and 1255, $1604 \mathrm{~cm}^{-1}$ are assigned to coordinated $\mathrm{NH}_{3}$ adsorbed on Lewis acid sites, the bands at 1469 and $1734 \mathrm{~cm}^{-1}$ are assigned to $\mathrm{NH}^{4+}$ ions located on Brønsted acid sites. ${ }^{19,33-36}$ And the band at $1519 \mathrm{~cm}^{-1}$ might be attributed to amide $\left(-\mathrm{NH}_{2}\right)$ species. ${ }^{19,37}$ With an increase in the exposure time, the intensities of all bands are obviously increased, indicating the increase in the amount of adsorbed $\mathrm{NH}_{3}$ species. After adding Ce in the $\mathrm{Cu}_{4} / \mathrm{ZSM}-5$ catalyst, its in situ DRIFT spectra are similar to that of the $\mathrm{Cu}_{4} / \mathrm{ZSM}-5$ catalyst. The coordinated $\mathrm{NH}_{3}$ adsorbed on Lewis acid sites (bands at 1158, 1253 and $1606 \mathrm{~cm}^{-1}$ ), and $\mathrm{NH}^{4+}$ ions located on Brønsted acid sites (bands at 1469 and $1734 \mathrm{~cm}^{-1}$ ) are also presented, and their intensities are increased obviously with the increase in the exposure time of $\mathrm{NH}_{3}$. As shown in Fig. 11, Lewis acid sites on the two catalysts are dominant to adsorb or activate $\mathrm{NH}_{3}$ compared with Brønsted acid sites, because most of Brønsted acid sites have been substituted by $\mathrm{Ce}$ or $\mathrm{Cu}$ ions. ${ }^{38}$

After the experiments of Fig. 11 were finished, the catalyst was purged with $\operatorname{Ar}\left(50 \mathrm{~mL} \mathrm{~min}^{-1}\right)$ for $1 \mathrm{~h}$, and then was exposed to $500 \mathrm{ppm} \mathrm{NO}+5$ vol\% $\mathrm{O}_{2} / \mathrm{Ar}\left(50 \mathrm{~mL} \mathrm{~min}^{-1}\right)$. In situ DRIFT spectra of the catalyst were taken for different times and are presented in Fig. 12.

As shown in Fig. 12A, when $\mathrm{NO}+\mathrm{O}_{2}$ is exposed to $\mathrm{NH}_{3}$-pretreated $\mathrm{Cu}_{4} / \mathrm{ZSM}-5$ catalyst, the intensities of the bands at 1159, $1255,1604,1519$ and $1734 \mathrm{~cm}^{-1}$ decreased gradually with the increase in the exposure time of $\mathrm{NO}+\mathrm{O}_{2}$, which indicates that both $\mathrm{NH}_{3}$ species adsorbed on Lewis acid sites and $\mathrm{NH}_{4}{ }^{+}$ions located on Brønsted acid sites are involved in the $\mathrm{NH}_{3}$-SCR reaction. At the same time, many new bands at 1678 and 1569 $\mathrm{cm}^{-1}$ ascribed to nitrates species appeared and increased with the increase of the exposure time in $\mathrm{NO}+\mathrm{O}_{2}$. After adding Ce, the bands assigned to adsorbed $\mathrm{NH}_{3}$ species decreased more
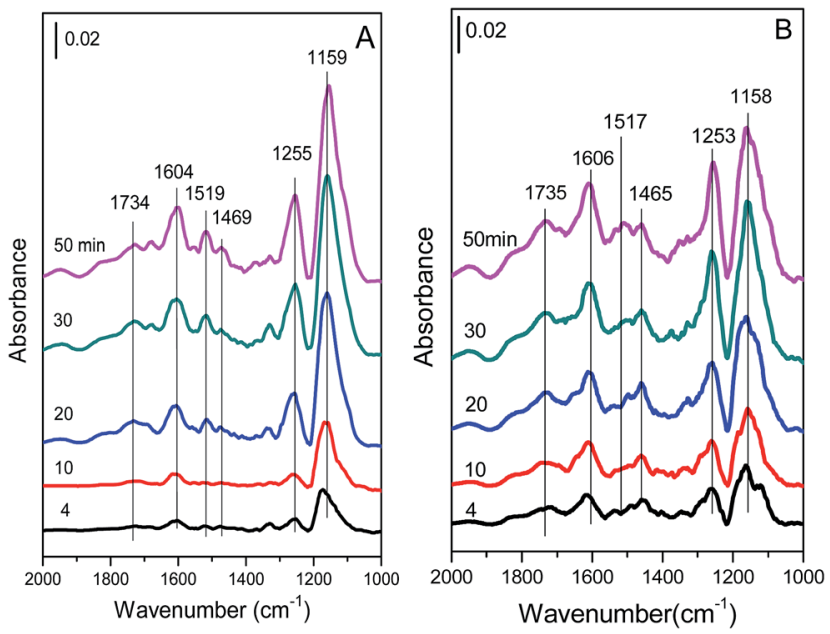

Fig. 11 In situ DRIFT spectra of (A) $\mathrm{Cu}_{4} / \mathrm{ZSM}-5$ and (B) $\mathrm{Ce}_{1}-\mathrm{Cu}_{4} / \mathrm{ZSM}-5$ catalysts exposed to a flow of $500 \mathrm{ppm} \mathrm{NH}_{3} / \mathrm{Ar}\left(50 \mathrm{~mL} \mathrm{~min}^{-1}\right)$ at $150^{\circ} \mathrm{C}$ for different times. quickly on the $\mathrm{Ce}_{1}-\mathrm{Cu}_{4} / \mathrm{ZSM}-5$ catalyst with the increase in the exposure time of $\mathrm{NO}+\mathrm{O}_{2}$ (Fig. 12B), indicating the higher SCR activity compared with the $\mathrm{Cu}_{4} / \mathrm{ZSM}-5$ catalyst.

3.6.2 Adsorption of $\mathrm{NO}+\mathrm{O}_{2}$ followed by introduction of $\mathbf{N H}_{3}$. Prior to the adsorption of $\mathrm{NO}+\mathrm{O}_{2}$, the catalyst was pretreated at $500{ }^{\circ} \mathrm{C}$ in $\operatorname{Ar}\left(50 \mathrm{~mL} \mathrm{~min}^{-1}\right)$ for $1 \mathrm{~h}$. After the catalyst was cooled down to $150{ }^{\circ} \mathrm{C}$, Ar gas was replaced by the mixed gas of $500 \mathrm{ppm} \mathrm{NO}+5 \mathrm{vol} \% \mathrm{O}_{2} / \mathrm{Ar}\left(50 \mathrm{~mL} \mathrm{~min}^{-1}\right)$, and in situ DRIFT spectra of the $\mathrm{Cu}_{4} / \mathrm{ZSM}-5$ and $\mathrm{Ce}_{1}-\mathrm{Cu}_{4} / \mathrm{ZSM}-5$ catalysts were taken for different times, and their results are shown in Fig. 13.

As shown in Fig. 13A, there are three strong bands at 1679, 1628 and $1568 \mathrm{~cm}^{-1}$ in the DRIFT spectra of the $\mathrm{Cu}_{4} / \mathrm{ZSM}-5$ catalyst. The bands at 1628 and $1568 \mathrm{~cm}^{-1}$ are assigned to bridged and bidentate nitrates respectively, ${ }^{39-42}$ and the band at $1679 \mathrm{~cm}^{-1}$ is attributed to ionic nitrite species. ${ }^{43,44}$ These bands were increased with the exposure time. Besides, there are still three bands with low intensity at 1438, 1303 and $1200 \mathrm{~cm}^{-1}$ in the DRIFT spectra of the $\mathrm{Cu}_{4} / \mathrm{ZSM}-5$ catalyst. These bands are assigned to nitrite species. ${ }^{\mathbf{4 2 , 4 4 , 4 5}}$

Compared with the in situ DRIFT spectra of the $\mathrm{Cu}_{4} / \mathrm{ZSM}-5$ catalyst, the strong absorption bands at 1679, 1626 and 1569 $\mathrm{cm}^{-1}$ are also shown in the in situ DRIFT spectra of the $\mathrm{Ce}_{1}-\mathrm{Cu}_{4} /$ ZSM-5 catalyst (Fig. 13B), but the intensity of the absorption band at $1679 \mathrm{~cm}^{-1}$ corresponding to ionic nitrite species is much lower than those at 1626 and $1569 \mathrm{~cm}^{-1}$. This is because that the higher oxidation of the $\mathrm{Ce}_{1}-\mathrm{Cu}_{4} / \mathrm{ZSM}-5$ catalyst (as shown in $\mathrm{H}_{2}$-TPR results) can easily oxidize ionic nitrite species to nitrates, resulting in the reduction in the ionic nitrite species on the $\mathrm{Ce}_{1}-\mathrm{Cu}_{4} / \mathrm{ZSM}-5$ catalyst surface. At the same time, the intensities of the bands at 1438 and $1303 \mathrm{~cm}^{-1}$ are much low, and the band at $1200 \mathrm{~cm}^{-1}$ assigned to bridged nitrite has even disappeared. Since nitrates are the active species for the SCR reaction, the highly catalytic activity of the $\mathrm{Ce}_{1}-\mathrm{Cu}_{4} / \mathrm{ZSM}-5$ catalyst for the oxidation of nitrite to nitrate is favorable for the better SCR activity.
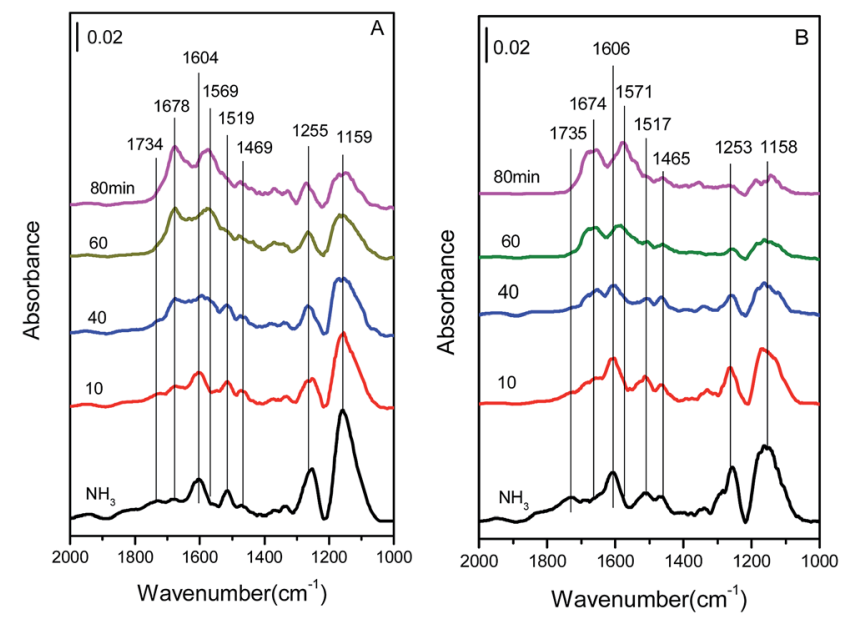

Fig. 12 In situ DRIFT spectra of (A) $\mathrm{Cu}_{4} / \mathrm{ZSM}-5$ and (B) $\mathrm{Ce}_{1}-\mathrm{Cu}_{4} / \mathrm{ZSM}$ 5 catalysts in the mixed gas of $500 \mathrm{ppm} \mathrm{NO}+5 \mathrm{vol} \% \mathrm{O}_{2} / \mathrm{Ar}$ at different

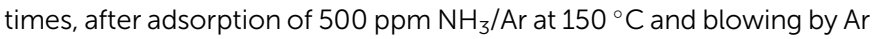
for $1 \mathrm{~h}$. 

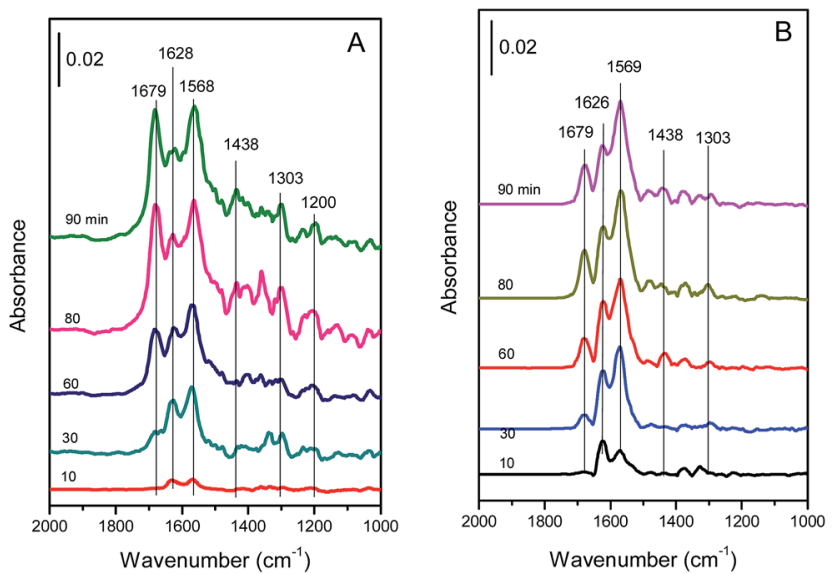

Fig. 13 In situ DRIFT spectra of the (A) $\mathrm{Cu}_{4} / \mathrm{ZSM}-5$ and (B) $\mathrm{Ce}_{1}-\mathrm{Cu}_{4} /$ ZSM-5 catalysts exposed to a flow of $500 \mathrm{ppm} \mathrm{NO}+5$ vol\% $\mathrm{O}_{2} / \mathrm{Ar}$ $\left(50 \mathrm{~mL} \mathrm{~min}{ }^{-1}\right.$ ) at $150{ }^{\circ} \mathrm{C}$ for different times.

To study the reaction between $\mathrm{NH}_{3}$ and adsorbed $\mathrm{NO}_{x}$ species, after the experiments of Fig. 13 were finished, the catalyst was purged with $\mathrm{Ar}\left(50 \mathrm{~mL} \mathrm{~min}^{-1}\right)$ for $1 \mathrm{~h}$, and then was

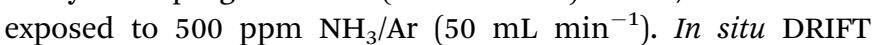
spectra of the catalyst were taken for different times and their results are presented in Fig. 14.

As shown in Fig. 14A, the intensities of the bands at 1568 $\mathrm{cm}^{-1}$ (assigned to bidentate nitrate) and $1628 \mathrm{~cm}^{-1}$ (assigned to bridged nitrate) decreased quickly with the increase of the exposure time in $500 \mathrm{ppm} \mathrm{NH}_{3}$, indicating that bidentate and bridged nitrates are the reactive species with a high activity for the SCR reaction. On the contrast, the intensity of band at 1679 $\mathrm{cm}^{-1}$ (assigned to ionic nitrite species) was hardly changed even after $\mathrm{NH}_{3}$ was passed over the catalyst for $80 \mathrm{~min}$, showing that this species is inactive in SCR process. Simultaneously, the bands at 1159, 1255 and $1606 \mathrm{~cm}^{-1}$ originating from $\mathrm{NH}_{3}$ adsorption species appear, and their intensities increase with the increase of the exposure time in $\mathrm{NH}_{3}$.
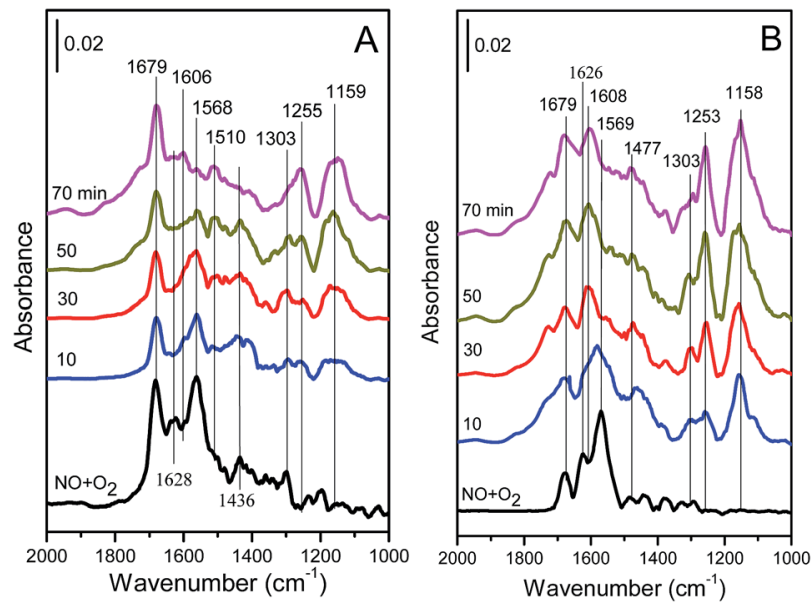

Fig. 14 In situ DRIFT spectra over (A) $\mathrm{Cu}_{4} / \mathrm{ZSM}-5$ and (B) $\mathrm{Ce}_{1}-\mathrm{Cu}_{4} /$

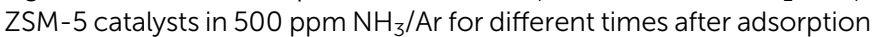
of $500 \mathrm{ppm} \mathrm{NO}+5 \mathrm{vol} \% \mathrm{O}_{2} / \mathrm{Ar}$ at $150^{\circ} \mathrm{C}$ and blowing by Ar for $1 \mathrm{~h}$.
Like the DRIFT results of the $\mathrm{Cu}_{4} / \mathrm{ZSM}-5$ catalyst, the intensities of the bands at $1569 \mathrm{~cm}^{-1}$ and $1626 \mathrm{~cm}^{-1}$ over the $\mathrm{Ce}_{1}-\mathrm{Cu}_{4} / \mathrm{ZSM}-5$ catalyst decreased with the increase in the exposure time of $\mathrm{NH}_{3}$, and these two bands disappeared after $30 \mathrm{~min}$, which is less than that for the disappearance of these two bands over the $\mathrm{Cu}_{4} / \mathrm{ZSM}-5$ catalyst $(60 \mathrm{~min})$, indicating a high SCR activity of the $\mathrm{Ce}_{1}-\mathrm{Cu}_{4} / \mathrm{ZSM}-5$ catalyst. On the contrary, the variation of the band at $1679 \mathrm{~cm}^{-1}$ was unobvious with the time. At the same time, the bands at 1158, 1253, 1477 and $1608 \mathrm{~cm}^{-1}$ originating from $\mathrm{NH}_{3}$ adsorption species appeared, and their intensities increased with the increase of the exposure time in $\mathrm{NH}_{3}$. Compared with the DRIFT results of the $\mathrm{Cu}_{4} / \mathrm{ZSM}-5$ catalyst, the intensities of the bands assigned to $\mathrm{NH}_{3}$ adsorption species over the $\mathrm{Ce}_{1}-\mathrm{Cu}_{4} / \mathrm{ZSM}-5$ catalyst are higher.

3.6.3 Proposed reaction pathway. As shown in Fig. $11, \mathrm{NH}_{3}$ mainly adsorbed on Lewis acid sites, as well as a little on Brønsted acid sites, and both $\mathrm{NH}_{3}$ species adsorbed on Lewis acid sites and Brønsted acid sites are involved in the $\mathrm{NH}_{3}$-SCR reaction. As a result, the bands corresponding to $\mathrm{NH}_{3}$ adsorption in in situ DRIFT spectra (Fig. 12) decreased gradually when the catalysts pretreated with $\mathrm{NH}_{3}$ are exposed to the mixed gas of $\mathrm{NO}$ and $\mathrm{O}_{2}$.

For the $\mathrm{Ce}_{1}-\mathrm{Cu}_{4} / \mathrm{ZSM}-5$ catalyst, the bands assigned to adsorbed $\mathrm{NH}_{3}$ species on the $\mathrm{Ce}_{1}-\mathrm{Cu}_{4} / \mathrm{ZSM}-5$ catalyst was decreased more quickly with the increase in the exposure time of $\mathrm{NO}+\mathrm{O}_{2}$ (Fig. 12B), indicating its higher SCR activity than the $\mathrm{Cu}_{4} / \mathrm{ZSM}-5$ catalyst. As shown in Fig. 13, the NO species can adsorb on the surface of the $\mathrm{Cu}_{4} / \mathrm{ZSM}-5$ and $\mathrm{Ce}_{1}-\mathrm{Cu}_{4} / \mathrm{ZSM}-5$ catalysts in the forms of bridged and bidentate nitrates, ionic nitrite and nitrate, and bridged nitrite. The nitrite species tend to be oxidized to nitrate species over the $\mathrm{Ce}_{1}-\mathrm{Cu}_{4} / \mathrm{ZSM}-5$ catalyst, because of its high catalytic activity for the oxidation reaction. When the catalysts pretreated with the mixed gas of $\mathrm{NO}$ and $\mathrm{O}_{2}$ were exposed to $\mathrm{NH}_{3}$, bidentate nitrate and bridged nitrate were consumed very quickly, while ionic nitrite species was hardly changed. These results indicate that bidentate nitrate and bridged nitrate over the $\mathrm{Cu}_{4} / \mathrm{ZSM}-5$ and $\mathrm{Ce}_{1}-\mathrm{Cu}_{4} /$ ZSM-5 catalysts are the reactive species with a high SCR reactivity, and the SCR reaction is followed Langmuir-Hinshelwood mechanism over the $\mathrm{Cu}_{4} / \mathrm{ZSM}-5$ and $\mathrm{Ce}_{1}-\mathrm{Cu}_{4} / \mathrm{ZSM}-5$ catalysts.

As above mentioned, when the catalysts pretreated with the mixed gas of $\mathrm{NO}$ and $\mathrm{O}_{2}$ were exposed to $\mathrm{NH}_{3}$, bidentate nitrate and bridged nitrate consumed very quickly and disappeared after 30 or $60 \mathrm{~min}$ (Fig. 14). However, when the catalysts pretreated with $\mathrm{NH}_{3}$ were exposed to the mixed gas of $\mathrm{NO}$ and $\mathrm{O}_{2}$, the bands corresponding to $\mathrm{NH}_{3}$ adsorption in in situ DRIFT spectra (Fig. 12) decreased gradually, and a part of $\mathrm{NH}_{3}$ species adsorbed on the catalysts surface remained still after $80 \mathrm{~min}$. Therefore, when the catalysts pretreated with $\mathrm{NH}_{3}$ were exposed to the mixed gas of $\mathrm{NO}$ and $\mathrm{O}_{2}$, NO maybe adsorbed on the surface of catalysts pretreated with $\mathrm{NH}_{3}$ firstly and then reacted with pre-adsorbed $\mathrm{NH}_{3}$, resulting in the low reaction rate. Therefore, it can't be confirmed whether the SCR reaction over the $\mathrm{Cu}_{4} / \mathrm{ZSM}-5$ and $\mathrm{Ce}_{1}-\mathrm{Cu}_{4} / \mathrm{ZSM}-5$ catalysts is followed EleyRideal mechanism. 


\subsection{Effect of $\mathrm{SO}_{2}$ and $\mathrm{H}_{2} \mathrm{O}$ on the SCR reaction}

Fig. 15 shows the effect of $\mathrm{SO}_{2}$ and $\mathrm{H}_{2} \mathrm{O}$ on the catalytic activities of the $\mathrm{Cu}_{4} / \mathrm{ZSM}-5$ and $\mathrm{Ce}_{1}-\mathrm{Cu}_{4} / \mathrm{ZSM}-5$ catalysts for the SCR reaction at $200{ }^{\circ} \mathrm{C}$. Before adding $\mathrm{H}_{2} \mathrm{O}$ or $\mathrm{SO}_{2}, \mathrm{NO}_{x}$ conversion was $100 \%$ over the two catalysts and their activities was unchanged after $20 \mathrm{~h}$ of the reaction at $200{ }^{\circ} \mathrm{C}$. When $2 \% \mathrm{H}_{2} \mathrm{O}$ was introduced into the feed gas, $\mathrm{NO}_{x}$ conversion over the $\mathrm{Cu}_{4} /$ ZSM-5 catalysts immediately decreased to $90.2 \%$ after $8 \mathrm{~h}$ of the reaction. After $2 \% \mathrm{H}_{2} \mathrm{O}$ in the feed gas was removed and lasting for $2 \mathrm{~h}$, the $\mathrm{NO}_{x}$ conversion was returned to $\sim 100 \%$. After adding $\mathrm{Ce}$ in the $\mathrm{Cu}_{4} / \mathrm{ZSM}-5$ catalyst, its performance for $\mathrm{H}_{2} \mathrm{O}$ resistance was improved, for instance, the $\mathrm{NO}_{x}$ conversion could hold $\sim 94 \%$ in the presence of $2 \%$ water. And its $\mathrm{NO}_{x}$ conversion was returned to $\sim 100 \%$ after removing $2 \% \mathrm{H}_{2} \mathrm{O}$ in the feed gas and lasting for $1.5 \mathrm{~h}$. A similar trend can also be observed at high reaction temperature $\left(450{ }^{\circ} \mathrm{C}\right)$ over the $\mathrm{Cu}_{4} /$ ZSM-5 and $\mathrm{Ce}_{1}-\mathrm{Cu}_{4} / \mathrm{ZSM}-5$ catalysts (Fig. $\mathrm{S} 2 \dagger$ ).

When 50 ppm $\mathrm{SO}_{2}$ was introduced into the feed gas, $100 \%$ $\mathrm{NO}_{x}$ conversion over the $\mathrm{Cu}_{4} / \mathrm{ZSM}-5$ catalysts was kept for $8 \mathrm{~h}$ and then decreased to $70.4 \%$ after the reaction of $6 \mathrm{~h}$, but the deactivation of catalyst poisoned by $\mathrm{SO}_{2}$ could not be recovered. However, it is obvious that the catalytic activity of the $\mathrm{Ce}_{1}-\mathrm{Cu}_{4} /$ ZSM-5 catalyst was less affected by $\mathrm{SO}_{2}$ than the $\mathrm{Cu}_{4} / \mathrm{ZSM}-5$ catalyst, that is to say, the Ce doping can improve the $\mathrm{SO}_{2}$ resistance of the $\mathrm{Cu}_{4} / \mathrm{ZSM}-5$ catalyst. A similar trend can also be observed at high reaction temperature over the $\mathrm{Cu}_{4} / \mathrm{ZSM}-5$ and $\mathrm{Ce}_{1}-\mathrm{Cu}_{4} / \mathrm{ZSM}-5$ catalysts (Fig. S2 $\dagger$ ). It is well known that the ammonium sulfate and copper sulfate deposited on the catalyst surface can cover available active sites and block zeolite channels, ${ }^{46}$ and they could not be decomposed and removed at 200 ${ }^{\circ} \mathrm{C}$ on the catalyst surface, ${ }^{47}$ resulting in a deactivation of catalyst. The presence of $\mathrm{Ce}$ in the $\mathrm{Cu}_{4} / \mathrm{ZSM}-5$ catalyst can make $\mathrm{SO}_{2}$ firstly deposit on the Ce site to form a stable Ce sulfate, which can inhibit the formation of ammonium sulfate and copper

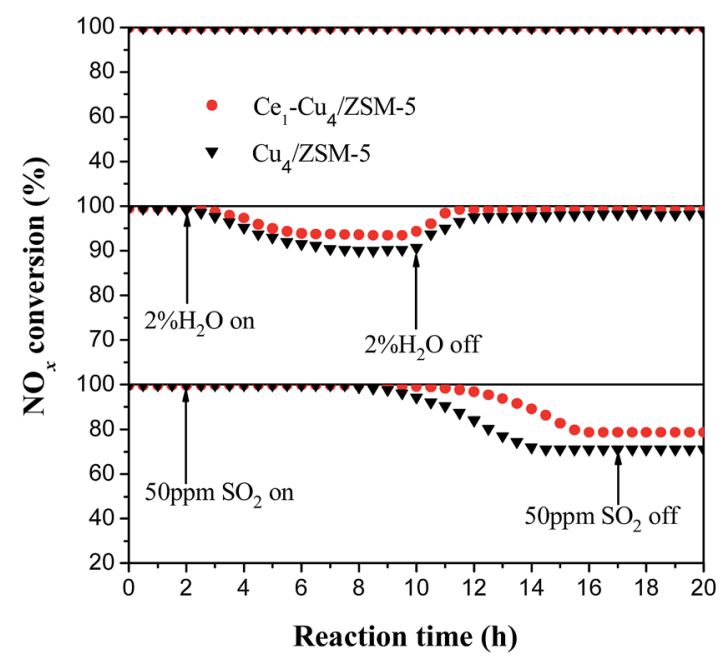

Fig. 15 Effect of $\mathrm{SO}_{2}$ and $\mathrm{H}_{2} \mathrm{O}$ on the catalytic activities of $\mathrm{Cu}_{4} / Z \mathrm{SM}-5$ and $\mathrm{Ce}_{1}-\mathrm{Cu}_{4} / \mathrm{ZSM}-5$ catalysts for $\mathrm{SCR}$ reaction at $200{ }^{\circ} \mathrm{C}$. (Reaction conditions: $0.2 \mathrm{~g}$ catalyst, $500 \mathrm{ppm} \mathrm{NO}, 500$ ppm NH $\mathrm{NH}_{3}, 5 \mathrm{O}_{2}$, Ar to balance, GHSV $=55000 \mathrm{~h}^{-1}$ ). sulfate on the catalyst surface in the SCR process, improving the excellent sulfur tolerance of the $\mathrm{Ce}_{1}-\mathrm{Cu}_{4} / \mathrm{ZSM}-5$ catalyst.

\section{Conclusions}

In summary, the addition of Ce can markedly improve the catalytic activity of the $\mathrm{Cu} / \mathrm{ZSM}-5$ catalyst for $\mathrm{NH}_{3}$-SCR reaction and enhance its $\mathrm{SO}_{2}$ and water resistance. Adding $\mathrm{Ce}$ in the $\mathrm{Cu}_{4} /$ ZSM-5 catalyst promoted the enrichment of copper species on the catalyst surface and increased the surface concentrations of both isolated $\mathrm{Cu}^{2+}$ ions and $\mathrm{CuO}$ crystallites, resulting in the improvement of the redox properties and the NO adsorption ability of the $\mathrm{Cu}_{4} / \mathrm{ZSM}-5$ catalyst. The Ce amount would affect the catalytic performance of $\mathrm{Ce}_{x}-\mathrm{Cu} / \mathrm{ZSM}-5$, especially the $\mathrm{NH}_{3}-\mathrm{SCR}$ activity at high temperature. When the $\mathrm{Ce}_{1}-\mathrm{Cu}_{4} / \mathrm{ZSM}-5$ catalyst $(\mathrm{Ce} / \mathrm{Cu}=1 / 4, \mathrm{wt})$ was used, the temperature window for more than $90 \% \mathrm{NO}_{x}$ conversion was extended to $185-470{ }^{\circ} \mathrm{C}$, which broadened the operation window about $45{ }^{\circ} \mathrm{C}$, because more nitrite and nitrate species on the $\mathrm{Ce}_{1}-\mathrm{Cu}_{4} / \mathrm{ZSM}-5$ catalyst surface can participate the SCR reaction than that on the surface of the $\mathrm{Cu}_{4} / \mathrm{ZSM}-5$ catalyst, and the Ce-doping sample can adsorb NO at lower temperature. In situ DRIFTS results indicated that the Langmuir-Hinshelwood mechanism for the $\mathrm{NH}_{3}$-SCR reaction over the $\mathrm{Cu}_{4} / \mathrm{ZSM}-5$ and $\mathrm{Ce}_{1}-\mathrm{Cu}_{4} / \mathrm{ZSM}-5$ catalysts was confirmed, but Eley-Rideal mechanism can't be sure yet.

\section{Acknowledgements}

This work was supported financially by the National Natural Science Foundation of China (21577034, 21333003), the Commission of Science and Technology of Shanghai Municipality (15DZ1205305) and the Fundamental Research Funds for the Central Universities (WJ1514020).

\section{Notes and references}

1 A. Brückner, F. Hipler, G. Auer, E. Löffler and W. Grünert, J. Catal., 2012, 286, 237.

2 Z. M. Liu, J. H. Li and S. I. Woo, Energy Environ. Sci., 2012, 5, 8799.

3 W. P. Shan, F. D. Liu, H. He, X. Y. Shi and C. B. Zhang, Catal. Today, 2012, 184, 160.

4 M. J. Li, Y. Yeom, E. Weitz and W. M. H. Sachtler, J. Catal., 2005, 235, 201.

5 X. F. Yang, Z. L. Wu, M. Moses-Debusk, D. R. Mullins, S. M. Mahurin, R. A. Geiger, M. Kidder and C. K. Narula, J. Phys. Chem. C, 2012, 116, 23322.

6 H. Sjövall, L. Olsson, E. Fridell and R. J. Blint, Appl. Catal., B, 2006, 64, 180.

7 G. Carja, Y. Kameshima, K. Okada and C. D. Madhusoodana, Appl. Catal., B, 2007, 73, 60.

$8 \mathrm{~J}$. L. de Lucas, F. Valverde, A. Dorado and I. Romero, J. Mol. Catal. A: Chem., 2005, 225, 47.

9 J. H. Park, H. J. Park, J. H. Baik, I. S. Nam, C. H. Shin, J. H. Lee, B. K. Cho and S. H. Oh, J. Catal., 2006, 240, 47.

10 X. F. Tang, Y. G. Li, X. M. Huang, Y. D. Xu, H. Q. Zhu, J. G. Wang and W. J. Shen, Appl. Catal., B, 2006, 62, 265. 
11 G. Carja, Y. Kameshima, K. Okada and C. D. Madhusoodana, Appl. Catal., B, 2007, 73, 60.

12 Z. B. Wu, R. B. Jin, Y. Liu and H. Q. Wang, Catal. Commun., 2008, 9, 2217.

13 S. M. Lee, K. H. Park and S. C. Hong, Chem. Eng. J., 2012, 195-196, 323.

14 K. Liu, F. D. Liu, L. J. Xie, W. P. Shan and H. He, Catal. Sci. Technol., 2015, 5, 2290.

15 Y. P. Zhang and M. Flytzani-Stephanopoulos, J. Catal., 1996, 164, 131.

16 J. Y. Yan, W. M. H. Sachtler and H. H. Kung, Catal. Today, 1997, 33, 279.

17 L. Pang, C. Fan, L. N. Shao and K. P. Song, Chem. Eng. J., 2014, 253, 394.

18 B. J. Dou, G. Lv, C. Wang, Q. Hao and K. Hui, Chem. Eng. J., 2015, 270, 549.

19 F. Bin, Appl. Catal., B, 2014, 150-151, 532.

20 B. Pereda-Ayo, U. D. L. Torre, M. J. Illán-Gómez, A. BuenoLópez and J. R. González-Velasco, Appl. Catal., B, 2014, $147,420$.

21 L. Wang, J. R. Gaudet, W. Li and D. Weng, J. Catal., 2013, 306, 68.

22 M. H. Groothaet, J. A. van Bokhoven, A. A. Battiston, B. M. Weckhuysen and R. A. Schoonheydt, J. Am. Chem. Soc., 2003, 125, 7629.

23 T. Zhang, J. Liu, D. Wang, Z. Zhao, Y. Wei, K. Cheng, G. Jiang and A. Duan, Appl. Catal., B, 2014, 148-149, 520.

24 S. Yashnik and Z. Ismagilov, Appl. Catal., B, 2015, 170-171, 241.

25 Y. Fu, W. Zhan, Y. Guo, Y. Wang, X. Liu, Y. Guo, Y. Wang and G. Lu, Microporous Mesoporous Mater., 2015, 214, 101.

26 T. Zhang, J. Liu, D. X. Wang, Z. Zhao, Y. C. Wei, K. Cheng, G. Y. Jiang and A. J. Duan, Appl. Catal., B, 2014, 148-149, 520.

27 G. H. Kuehl and H. K. C. Timken, Microporous Mesoporous Mater., 2000, 35-36, 521.

28 L. J. Lobree, I. C. Hwang and J. A. Reimer, J. Catal., 1999, 186, 242-253.
29 X. Liang, J. X. Li, Q. C. Lin and K. Q. Sun, Catal. Commun., 2007, 8, 1901.

30 X. D. Wu, F. Lin, H. B. Xu and D. Weng, Appl. Catal., B, 2010, 96, 101.

31 A. de Lucas, J. L. Valverde, F. Dorado, A. Romero and I. Asencio, J. Mol. Catal. A: Chem., 2005, 225, 47.

32 J. Chen, M. Shen, X. Wang, G. Qi, J. Wang and W. Li, Appl. Catal., B, 2013, 251, 134.

33 L. Wang, W. Li, S. J. Schmieg and D. Weng, J. Catal., 2015, 324, 98.

34 F. Gao, J. H. Kwak, J. Szanyi and C. H. F. Peden, Top. Catal., 2013, 56, 1441.

35 H. Y. Zhu, J. H. Kwak, C. H. F. Peden and J. Szanyi, Catal. Today, 2013, 205, 16.

36 L. Wang, W. Li, G. S. Qi and D. Weng, J. Catal., 2012, 289, 21. 37 W. S. Kijlstra, D. S. Brands, H. I. Smit, E. K Poels and A. Bliek, J. Catal., 1997, 171, 219.

38 S. Brandenberger, O. Kröcher, A. Wokaun, A. Tissler and R. Althoff, J. Catal., 2009, 268, 297.

39 W. Shan, F. Liu, H. He, X. Shi and C. Zhang, Appl. Catal., B, 2012, 115-116, 100.

40 S. Liu, X. D. Wu, D. Weng and R. Rani, Ind. Eng. Chem. Res., 2012, 51, 2271.

41 R. D. Zhang, W. Yang, N. Luo, P. X. Li, Z. G. Lei and B. H. Chen, Appl. Catal., B, 2014, 146, 94.

42 J. Szanyi, J. H. Kwak, H. Y. Zhu and C. H. F. Peden, Phys. Chem. Chem. Phys., 2013, 15, 2368.

43 K. Hadjiivanov, A. Penkova, M. Daturi, J. Saussey and J. C. Lavalley, Chem. Phys. Lett., 2003, 377, 642.

44 K. I. Hadjiivanova, Catal. Rev.: Sci. Eng., 2000, 42, 71.

45 I. Atribak, B. Azambre, A. Bueno López and A. García-García, Appl. Catal., B, 2009, 92, 126.

46 Z. X. Ma, H. S. Yang, F. Liu and X. B. Zhang, Appl. Catal., A, 2013, 467, 450.

47 J. Yu, F. Guo, Y. L. Wang, J. H. Zhu, Y. Y. Liu and F. B. Su, Appl. Catal., B, 2010, 95, 160. 